\title{
Changes of Milk Production and Reproductive Performance of Dairy Buffaloes in Nepal During Recent 15 Years
}

\author{
Y. Hayashi ${ }^{1, *}$, M.K. Shah ${ }^{2}$ and H. Kumagai ${ }^{3}$ \\ ${ }^{1}$ Experimental Farm, Faculty of Agriculture, Meijo University, Kasugai, 486-0804, Japan \\ ${ }^{2}$ Regional Agricultural Research Station, Nepal Agricultural Research Council, Lumle, Nepal \\ ${ }^{3}$ Graduate School of Agriculture, Kyoto University, Kyoto, 606-8502, Japan
}

\begin{abstract}
Consumption of buffalo milk has been increasing in Nepal. Thus, further development of dairy buffalo is required for efficient production. However, the changes of milk production and reproductive performance of buffaloes in the country remain obscure. Hence, the study is conducted for identifying the dairy production and reproduction of buffaloes raised in Nepal during 15 years. The records of daily milk yield (MY) from July 1997 to July 2012 were collected at Livestock Development Farm, Nepal. Lactation MY, 305 days MY, lactation length, MY per day of lactation, peak MY, days to attain peak MY, calving interval and dry period were calculated. The results were summarized every 5 years (Period 1: July 1997 - July 2002, Period 2: July 2002 - July 2007, Period 3: July 2007 - July 2012). The lactation MY, 305 days MY, daily MY per lactation and peak MY were lower in Period 1 than in Period 2 and 3. On the other hand, the days to attain peak MY was longer in Period 1 than in the other periods. However, the lactation length had no significant difference among the periods. The milk production was assumed to improve from Period 1 to Period 2 and 3. The calving interval was longer in Period 3 than in Period 2. The dry period was longest in Period 3 . The efficiency of buffalo reproduction during the recent 5 years assumed to be declined. The deterioration of reproduction possibly has been caused by changes in nutritional and environmental conditions during the surveyed period.
\end{abstract}

Keywords: Buffalo, change, milk production, Nepal, reproduction.

\section{INTRODUCTION}

Buffaloes are essential animals which have been raised for draught, meat and dairy in Nepal for a long time. The milk yield (MY) of buffaloes was 1.1 million metric tons and contributed to $67.4 \%$ of the national milk production in 2011 [1]. The amount of consumption and supply of milk products has been growing in Nepal for the last decade [1, 2]. The major local milk products available in the markets are cheese, paneer, butter, ghee, ice cream and yoghurt [3]. The other various dairy products are imported for fulfilling the national dairy demand. However, there are several constraints relating to dairy buffalo development in the country, such as low milk productivity, inadequate breeding support services and feeding management. Therefore, the comprehensive study on improvement of dairy buffaloes in Nepal is required for the efficient production. A study had been conducted for identifying the trait of buffalo milk production in small-scale farms of the country. The buffalo daily MY in small-scale farms of Tarai region was from $6.4 \mathrm{~L}$ to $7.7 \mathrm{~L}$ [4]. The periods divided by the environments of pasture and fodder caused the variance in feed constituents. The variance induced different MY of buffaloes. The other researches were also done for improving the milk

*Address correspondence to this author at the Experimental Farm, Faculty of Agriculture, Meijo University, Kasugai, 486-0804, Japan; Tel: +81-568-81-2169; Fax: +81-568-81-1589; E-mail: yoshiha@meijo-u.ac.jp production of buffaloes in the country. The additional feeding of field pea hay tended to rise the milk production of buffaloes [5]. In addition, dairy buffaloes fed corn silage increased daily milk production and fat content in milk [6]. However, few studies have been conducted for improving the buffalo milk production in the country and there are still constraints for dairy buffalo development.

For further improvement of dairy productivity in Nepal, the past and present status of milk production and reproductive performance in dairy buffaloes should be understood. However, the transition of milk production and reproduction of dairy buffaloes in the country remains obscure. In the present study, an attempt has been conducted to identify the condition of milk production and reproductive performance of dairy buffaloes raised in a national dairy farm during the recent 15 years.

\section{MATERIALS AND METHODS}

\section{Data Collection Site and Animals}

The study was based on data which had been kept by Livestock Development Farm (LDF) in Lampatan, Pokhara, Kaski, Nepal. The farm was situated between $28^{\circ} 14^{\prime} \mathrm{N}$ latitude and $83^{\circ} 59^{\prime} \mathrm{E}$ longitude at an altitude of around $830 \mathrm{~m}$ above mean sea level in the Hill region of Nepal. The region was in a temperate climate with the average monthly temperature ranged from 
$15.2^{\circ} \mathrm{C}$ to $26.2^{\circ} \mathrm{C}$ and $3952 \mathrm{~mm}$ total precipitation from 1971 to 2011 (Normal Maximum, Minimum Temperature and Rainfall through 2000 year, Meteorological Forecasting Division, Government of Nepal). The buffaloes, had the first to fourth lactations, were housed in permanent sheds with open type ventilation and maintained under semi intensive feeding and management. Animals were fed Napier grass as roughage and commercial concentrate feed twice a day for fulfilling their energy and protein requirements, and grazed in pasture during day time.

Buffaloes were milked manually twice daily in early morning and afternoon, and each MY was determined using a weighing scale and recorded. In this survey, the data of milk contents and cost of MY was not collected due to the shortage of data accumulation during the survey period.

\section{Data Analysis}

Data of daily MY and reproductive performance were collected from the total 513 head of dairy Murrah buffaloes maintained under LDF for the period from July 15, 1997 to July 15, 2012. The traits studied were lactation MY, 305 days MY, lactation length, MY per day of lactation, peak MY, days to attain peak MY, calving interval and dry period. The results of the production and reproduction were summarized every 5 years (Period 1: from July 1997 to July 2002, Period 2: from July 2002 to July 2007, Period 3: from July 2007 to July 2012) and compared the means among the three periods.

The means of each period were adjusted for multiple comparisons and were separated statistically using Tukey's multiple range test. Significance was defined as $p<0.01$ or $p<0.05$.

\section{RESULTS AND DISCUSSION}

\section{Transition of Milk Production in Buffaloes}

Means of different production traits are presented in Table 1. The lactation MY and 305 days MY were significantly lower in Period 1 than in Period 2 and 3 $(p<0.01)$. On the other hand, the lactation length had no significant difference among the periods. Although the lactation length was similar among the three periods, the milk production was assumed to improve from Period 1 to Period 2 and 3. Therefore, the MY per day of lactation was significantly higher in Period 2 and 3 than in Period $1(p<0.01)$. The most buffaloes in Nepal were Indian Murrah buffaloes or their crossbreeds as a result of crossbreeding program and imports from India [7]. There has been some increase in milk production in the country as the result of the program of crossbreeding the indigenous buffalo with Indian Murrah. This trend was assumed to affect the improvement of milk production in the recent 10 years. In addition, Animal Breeding and Artificial Insemination Section of Department of Livestock Services has been utilizing Murrah frozen semen processed locally and imported from India for their insemination services [7]. The genetic improvement of buffaloes with the expansion of artificial insemination might have contributed to the development of milk production.

The population and total MY of lactating buffaloes were shown in Nepal every year [1]. According to these data, the average annual milk production of a buffalo can be calculated as $829 \mathrm{~kg}$ from 1997 to $2001,848 \mathrm{~kg}$ from 2002 to 2006 and $853 \mathrm{~kg}$ from 2007 to 2011 . The average milk production of the first 5 years from 1997 is significantly lower than that of the other years $(p<0.01)$. This transition coincides with the results of

Table 1: Milk Production Traits of the Buffaloes

\begin{tabular}{|c|c|c|c|}
\hline & Period 1 & Period 2 & Period 3 \\
\hline $\mathbf{n}$ & $\mathbf{1 7 4}$ & $\mathbf{1 9 1}$ & 148 \\
\hline \hline Lactation milk yield (kg) & $1263.3 \pm 34.4^{\mathrm{b}}$ & $1776.2 \pm 44.2^{\mathrm{a}}$ & $1562.3 \pm 38.3^{\mathrm{a}}$ \\
\hline 305 days milk yield (kg) & $1068.1 \pm 26.1^{\mathrm{b}}$ & $1731.4 \pm 39.2^{\mathrm{a}}$ & $333.3 \pm 8.1$ \\
\hline Lactation length (day) & $350.8 \pm 8.6$ & $355.3 \pm 6.9$ & $4.9 \pm 0.1^{\mathrm{a}}$ \\
\hline Daily milk yield (kg/day) & $3.6 \pm 0.1^{\mathrm{b}}$ & $4.9 \pm 0.1^{\mathrm{a}}$ & $8.7 \pm 0.1^{\mathrm{a}}$ \\
\hline Peak milk yield (kg) & $7.3 \pm 0.3^{\mathrm{b}}$ & $8.7 \pm 0.1^{\mathrm{a}}$ & $104.4 \pm 6.4^{\mathrm{b}}$ \\
\hline Days to attain peak yield & $135.0 \pm 6.5^{\mathrm{a}}$ & $103.2 \pm 4.9^{\mathrm{b}}$ & $1^{\mathrm{a}}$ \\
\hline
\end{tabular}

Period 1: from July 1997 to July 2002, Period 2: from July 2002 to July 2007, Period 3: from July 2007 to July 2012. Mean \pm SE.

${ }^{\mathrm{ab}}$ Means within the different Period with superscripts significantly differ $(p<0.01)$. 
present survey. Thus, the milk production of buffaloes in Nepal was considered to improve in the time between Period 1 and 2.

The research on dairy production of lactating buffaloes in small-scale farms of Tarai, Nepal was conducted from 2002 to 2004 when these years belong to Period 2 in the present survey $[4,8]$. The average MY of 305 days lactation of the buffaloes was estimated from $1619 \mathrm{~L}$ to $2196 \mathrm{~L}$ in different parities. The lactation length was from 118 days to 173 days in the different survey periods. In addition, the daily MY of a buffalo in small-scale farms was reported from $6.4 \mathrm{~L}$ to $7.7 \mathrm{~L}$ [4]. In India, the average 305 days lactation of Murrah buffaloes raised from 1999 to 2002 and from 2003 to 2006 was $1974.1 \mathrm{~kg}$ and $1953.7 \mathrm{~kg}$, respectively. The same authors reported the lactation length of Murrah buffaloes raised in the same periods were 305.8 days and 292.5 days, respectively. In addition, the average daily MY of the same buffaloes from 1999 to 2006 was $6.66 \mathrm{~kg}$. Although the lactation days were longer in the present survey than in the past reports, the 305 days MY and daily MY in the present site were lower than the past records. The dissimilarity might have been attributed to the different genetic constitution of the herds, agro-climatic variations and a variety of feeding management among the research sites.

The peak MY was significantly lower in Period 1 than in Period 2 and $3(p<0.01)$. On the other hand, the days to attain peak MY were significantly longer in Period 1 than in the other periods. Peak MY was reported to significantly correlate with lactation yield indicating that buffaloes attaining higher peak yield were having higher MY in lactation [9]. This report supported the increased lactation MY observed from Period 1 to Period 2 and 3 in the present survey. The average peak MY of Murrah buffaloes raised in India from 1999 to 2002 and from 2003 to 2006 were $9.52 \mathrm{~kg}$ and $9.18 \mathrm{~kg}$, respectively [10]. The peak MY of the present study was lower than the values reported for Murrah buffaloes in India. In general, the time to reach peak MY was reported to be between 30 to 60 days. However, the days attain peak yield in the present study was substantially higher than that reported for Murrah buffaloes [10-12]. This condition in the present survey was probably caused by the inadequate nutrition and management especially in postpartum period. It is necessary to feed nutritional roughage and concentrate feed for keeping an adequate nutritional balance after parturition.

\section{Transition of Reproductive Performance in Buffaloes}

Means of different reproductive traits are presented in Table 2. The calving interval days were longer in Period 3 than in Period $2(p<0.01)$. Although the interval days showed no significant difference between Period 3 and Period 1 , the coefficient of variation in Period 3 was higher than in Period 1 (4.6\% vs. $2.8 \%$ ). The dry period was longer in Period 3 than in Period 1 and $2(p<0.05)$. The coefficient of variation in Period 3 was also higher than in the other periods $(8.3 \%$ vs. $4.4 \%$ in Period 1 and $4.9 \%$ in Period 2). The efficiency of the buffalo reproduction during the recent 5 years assumed to be declined. The mean calving interval and dry period recorded in the present survey were longer than the other reports on Murrah buffaloes [11]. The many factors such as postpartum oestrus days, service period, embryonic mortality, high milk production, seasonal and environmental conditions, age of cows and sire used for reproduction have been implicated for calving interval and dry period of buffaloes. In general, the productivity of buffaloes in Nepal is reported to be still low. One of the reasons for the low condition is degradation of reproduction in buffaloes. Anestrus due to ovarian dysfunction and silent ovulation, and repeat breeding are major reproductive disorders. The main clinical features of repeat breeding buffaloes in Nepal were reported as a longer interval between calving and treatment, a relatively high incidence of cervicities [13]. The deterioration of reproductive performance possibly has been caused by changes in nutritional and environmental condition during the surveyed period. These issues should receive further attention.

The significant influence of period in the present study on milk production and reproduction traits was

Table 2: Reproductive Traits of the Buffaloes

\begin{tabular}{|c|c|c|c|}
\hline & Period 1 & Period 2 & Period 3 \\
\hline \hline Calving interval day & $661.3 \pm 18.3^{\mathrm{ab}}(\mathrm{n}=92)$ & $600.9 \pm 17.2^{\mathrm{b}}(\mathrm{n}=75)$ & $699.5 \pm 32.5^{\mathrm{a}}(\mathrm{n}=63)$ \\
\hline Dry period day & $305.7 \pm 13.3^{\mathrm{d}}(\mathrm{n}=103)$ & $255.1 \pm 12.5^{\mathrm{d}}(\mathrm{n}=87)$ & $371.5 \pm 30.8^{\mathrm{c}}(\mathrm{n}=82)$ \\
\hline
\end{tabular}

Period 1: from July 1997 to July 2002, Period 2: from July 2002 to July 2007, Period 3: from July 2007 to July 2012. Mean \pm SE. Means within the different Period with superscripts significantly differ $\left({ }^{(a b} p<0.01 ;{ }^{c d} p<0.05\right)$. 
supported by similar findings on Murrah buffaloes [12, 14, 15]. Thiruvenkadan and Panneerselvam [10] indicated the transition of milk production and reproduction might be attributed to differences in management practices, sires used for breeding, environmental conditions and variations in feed and fodder availabilities.

In conclusion, the dairy production of the buffaloes in Nepal was improved and maintained during the recent 15 years. However, the reproduction of the buffaloes tended to have constraints for efficient milk production. More attention for improving breeding and nutritional management should be paid. The further reformed management of raising environment for keeping health in buffaloes is also necessary for efficient dairy production.

\section{ACKNOWLEDGEMENTS}

The authors gratefully acknowledge Dr. N. P. Sharma and the staffs of Livestock Development Farm in Lampatan, Pokhara, Kaski, Nepal for providing the data and technical assistance in this study.

\section{REFERENCES}

[1] FAO. Livestock Primary, Production, FAOSTAT [homepage on the Internet]. Rome: Food and Agriculture Organization of the United Nations 2013; [cited 2014 April 17]; Available from:http://faostat.fao.org/site/569/DesktopDefault.aspx?Pag elD=569\#ancor

[2] FAO. Livestock Sector Brief, Nepal. Livestock Information, Sector Analysis and Policy Branch. Rome: Food and Agriculture Organization of the United Nations 2005

[3] FAO. Dairy Sector Study of Nepal. Kathmandu: Food and Agriculture Organization of the United Nations. FAO Nepal Representation 2010.
[4] Hayashi $Y$, Shah S, Shah SK, Kumagai H. Dairy production and nutritional status of lactating buffalo and cattle in smallscale farms in Terai, Nepal. Livest Res Rural Dev 2005 [cited 2014 April 17]; 17: 64. Available from:http://www. Irrd.org/lrrd17/6/haya17064.htm

[5] Hayashi $\mathrm{Y}$, Devkota NR, Kumagai H. Effects of field pea (Pisum sativum L.) hay feeding on dry matter intake and milk production of Murrah buffaloes (Bubalus bubalis) fed rice straw ad libitum. Anim Sci J 2007; 78: 151-8.

[6] Hayashi Y, Thapa BB, Sharma MP, Sapkota M, Kumagai H. Effects of maize (Zea mays L.) silage feeding on dry matter intake and milk production of dairy buffalo and cattle in Tarai, Nepal. Anim Sci J 2009; 80: 418-27.

[7] Rasali DP. Recent trends in buffalo production in Nepal - A review. Buffalo Newsletter (Bulletin of the FAO Inter-Regional Cooperative Research Network on Buffalo, Rome for EuropeNear East) 2000; 14: 6-10.

[8] Hayashi $\mathrm{Y}$, Maharjan KL, Kumagai $\mathrm{H}$. Feeding traits nutritional status and milk production of dairy cattle and buffalo in small-scale farms in Tarai, Nepal. Asian-Aust $\mathrm{J}$ Anim Sci 2006; 19: 189-97.

[9] Hamid SK, Farooq M, Mian MA, Syed M, Jamal S. Milk production performance and inter-relationship among traits of economic importance in buffaloes maintained at commercial dairy farms. Livest Res Rural Dev 2003; [cited 2014 April 17]; 15: 10. Available from: http://www.Irrd.org//lrd15/ 10/hamil510.htm

[10] Thiruvenkadan AK, Panneerselvam S. Milk production and reproductive performance of Murrah buffaloes in Tamil Nadu, India. In: Odongo NE, Garcia M, Viljoen GJ, editors. Sustainable improvement of animal production and health. Rome: Food and Agriculture Organization of the United Nations 2010; pp. 99-104.

[11] Kundu S, Pandey RS, Singh SK. Studies on some persistency traits in Murrah buffaloes. Indian J Anim Res 2003; 37: 28-31.

[12] Suresh R, Bidarkar DK, Gupta BR, Sudhakarro B, Sudhakar $\mathrm{K}$. Production and reproduction performance of Murrah buffaloes. Indian J Anim Sci 2004; 74: 854-7.

[13] Sah SK, Nakao T. Characteristics of repeat breeding buffaloes in Nepal. J Reprod Dev 2006; 52: 335-41.

[14] Sethi RK, Khatkar MS. Genetic parameters of production traits in Murrah buffaloes. Indian J Anim Sci 1997; 67: 141-2.

[15] Yadav BS, Yadav MC, Singh A, Khan FH. Study of economic traits in Murrah buffaloes. Buffalo Bull 2007; 26: 10-4. 